\title{
Juvenile Delinquency Dimension of Child Labour: Implications for Human and Capital Development in Nigeria
}

\author{
May Omogho Esiri \\ Department of Sociology and Psychology, Faculty of Social Science, Delta State University, \\ Abraka, Nigeria \\ Corresponding author email: esirimay@yahoo.com \\ Eucharia Ejechi \\ Department of Sociology and Psychology, Faculty of Social Science, Delta State University, \\ Abraka, Nigeria
}

\begin{abstract}
Juvenile delinquency and child labour are related social problems that today plague Nigeria. They both affect young boys and girls, some of whom are children (juveniles). Among these juveniles are children who have been involved in criminal behavior like gangism, banditry, thuggery, drug sales and abuse behaviors which are sometimes developed from participation in child labour activities which have become severe in Nigeria. Majority of these activities take the form of street hawking in the Southern part of the country, and street begging in its northern part by children addressed as Almajirai. These problems if allowed to remain will compromise and jeopardize not only the future of the child, but also that of the nation, Nigeria. Thus this study investigates juvenile delinquency as predated by child labour with a view to explaining causality and effects. Particularly, as it relates to human and capital development, and to make suggestions towards finding solutions.

Keywords---child labour, delinquency, development, dimension, Juvenile, young persons.
\end{abstract}

\section{Introduction}

Juvenile delinquency and child labour have in recent times become major issues in public discourse. Both phenomena are social problems that must be curtailed to avoid compromising the future life chances of the child and the demise of capital developments. The increase in child labour and the criminal activities of Nigeria's young person's has been attributed to institutional collapse in the decades of modernization and globalization - a situation which has been described in many ways by various scholars like (Ekpenyoung \& Sibiri, 2011; Okojie \& Effiong, 2014; Hassan et al., 2020).

According to Hassan et al. (2020), the history of juvenile delinquency in Nigeria is age-long, with its prevalence in the past not comparable to what it is today. They argue that the prevailing Nigerian cultural ideologies involve ensuring that children work with their families so that they can learn required skills for adult life. In addition, they observe that "there is a compulsion to work to ensure survival both for themselves as well as their families" (Hassan et al., 2020). A situation which Okojie \& Effiong (2014) have maintained, is resulting to a rising rate of participation of children in criminal activities. Such children who are involved in child labour due to poverty and socio-economic hardship in the family, spend most of their time out on the streets hawking/ begging and are most vulnerable to delinquency. However, the proceeds from their labour practice, contributes to the sustainance and livehood of the family. Bukoye \& Procedia (2015) reveals a progression of poverty rate in Nigeria as reported by Elembah (2012) as follows: " $27 \%$ in 1980 to $66 \%$ in 1996 , to $70 \%$ in 1999 ", and an estimated $85 \%$ and above Nigerians living in poverty in 2011 (Bukoye/ Procedia, 2015 p325). Also most recent, is the world Bank Brief Esiri (2020), which revealed the National Bureau of statistics' poverty report that 40 percent of Nigeria's total population of almost 83 million people live below the country’s poverty line of 137, 430 naira (\$381.75) per year (Esiri, 2020). 
The observations of Hassan et al. (2020), and Okojie \& Effiong (2014), along with these poverty reports have been the sources of concern and worry for many Nigerians and still is, today. Since socio-economic difficulties and hardships resulting from poverty are seen as the cause of premature labour which in turn leads to many more of children and young persons deviance, it may therefore be argued that there is a seemingly increasing child labour activity and a consequential increase in juvenile delinquency and harmful behaviours presently in Nigeria. This is not only alarming but dangerous for toady's, and most especially the future development of human and capital resources in terms of capital expenditure on rehabilitation/ treatment of juvenile drug abusers/ addicts, some of whom are sometimes apprehended by law maintenance agents. It is for this reason that this study set out to ascertain the outcomes or consequences and implication of the juvenile dimension of child labour and it's implication for the development of the child and the nation, Nigeria.

\section{Conceptual Clarification and Literature Review Child Labour}

\section{Child Labour}

According to Okeshola (1996), the definition of child labour is problematic. He cites an example of the definition of child labour by official statistics as that which is recorded in the formal sectors of the economy where children are remunerated for their work. But this he argues does not give an accurate picture of reality as it leaves out the majority of working children who work in the informal sector. This is because it raises the issues of whether both paid and unpaid labour should be regarded as work, bearing in mind that unremunerated jobs as in household chores can be tedious for the child as remunerated work outside the home. The hot debate of the issue of child labour in recent times has made an acceptable definition of the concept a difficult one.

However, to get to the significant part, the question 'who is a child?' Must be answered. The term 'child' is often used generally to refer to a person from birth to the legal age of maturity. Age of legal maturity varies from one country to another and from one society to another. Some countries or societies consider anyone who has developed disability, regardless of age, as a child (UNICEF, 2001). In the United States, child Abuse prevention and treatment of 1994 defines a child as anyone under the age of 18 (Okafor, 2000; Nelson \& Clark, 1986; Bingen et al., 2003; Čiutienè \& Railaite, 2015). But in general, the International labour Organisation (ILO) establishes 15 years as the minimum age for allowing children to work provided that fifteen (15) is not less than the age for completion of schooling. This has been the most widely used yardstick when establishing how many children around the world are currently working (ILO, 1996).

Children in all societies work but the type of work they do very within societies. Therefore labour is a global phenomenon found in all regions of the world, though overwhelmingly a developing country phenomenon. According to The African Union (2019) 1 in 5 children (a figure two times higher than in other parts of the World) engage in child labour in Africa. Concerning Nigeria, the statistical Information and Monitoring programme on Child Labour Survey (SIMPOC) 2006, established that there are about 15 million $(15,027,612)$ working children in Nigeria consisting of males, and 7,214, 856 females, of whom at least 6 million can be classified as child laborers. Child labour in Nigeria include serving as agricultural work domestic servants, commercial sex workers, street hawkers and/ or beggers and bus conductors. ILO (1996) reports that street hawking accounts for the highest percentage of informal economy and public places employment. Studies also reveal that one out of every three children in Lagos is a hawker, hundred percent of whom are school dropouts; for everywoman selling goods in the market, there are five children hawking, for every bus driver, there are two underage children working as bus conductors; and for every three house-helps one is underage (Oloko, 2003; United Nations International Children's Emergency fund, 1990). Interestingly Okeke (2015), also observed that street hawking is a common sight on the streets of Nigeria and it involves children selling products such as groundnuts, fruits and chips which is carried on their heads in trays. Similarly, the Almajirai system which is seen in Northern Nigeria depicts Koranic pupils who are left to roam the streets in large cities. Some of these children at the age of three years are entrusted to Islamic teachers who in turn rather than care for them as they grow, send them out in the streets to beg and do odd jobs (Ammani, 2009; Currie \& Almond, 2011; Darcy et al., 2014). While Esobonu (2012) observes an exponential growth in beggers population on the streets of Nigeria, Bukoye \& Procedia (2015) report that the presence of such on the streets of Suleja in the Northern part of Nigeria, is a recognized serious problem that requires urgent attention" (Bukoye \& Procedia, 2015). Children street beggers are expected to bring part of the proceeds of their activities to the Islamic teachers. The manifestations of child labour are many and they take many forms some of which may be unique to any one region of the world. Some of these forms particularly relevant to this study are as follows: 
- Domestic Service: Most Children laborers are in domestic service. It is often hazardous. Children in domestic servitude with or without their parents are poorly catered for. There are also cases of 'rented' child in which the master of the child sets terms and conditions of the work entirely at his/her own whom. The child in most cases is deprived of affection, adequate and functional schooling, play, and other social services. In the long run, such a child may be vulnerable to physical and sexual abuse and may run away from home into the streets (Joshi, 2020; Esiri, 2020). According to Joshi (2020), studies report that abused and neglected children are $25 \%$ more prone to delinquency, teenage pregnancy, use of drugs and others, and such children are targets of arrest for criminal behavior.

- Commercial Sex Exploitation: This is one of the most devastating forms of child abuse (Okafor \& Bode Okunade, 2004). Yet it is estimated that each year, at least one million girls worldwide are forced into sex trade (UNICEF, 1997). International Labour Organisation (ILO, 1998). However, boys are not left out in the social malaise. Sometimes the sexual abuse maybe by pedophiles which refers to sexual attraction towards the very young (Handbook of crime, 2011). Sometimes commercial sexual exploitation may be directly linked to forms of exploitative labour. For example, street hawkers in urban areas who are often mostly children, are common sites for exploitation and vulnerability to HIV. Also street hawking, according to Jacks, Ekeng \& James, is "considered a form of child abuse because it endangers the health (physical, spiritual, psychological, and social) and safety of the child; interferes with his/her education and deprives the right to normal and happy childhood" (Jacks et al., 2019; Fahimi et al., 2018; Galli \& Müller-Stewens, 2012).

- Street Hawking. This form of child labour is very common in the cities of developing countries such as Nigeria where incomes are low and have proved inadequate to cater for whole families. Under such circumstances both very young and older children are made to hawk along the streets in order to supplement the family income. Some commonly hawked items include soft drinks, fruits of every kind, cold water and other materials (Shinadi, 1986; Vinolia \& Futura, 1986; Okeke, 2015). Some studies conducted in major cities of Nigeria indicate that street hawking is the commonest form of child labour in the country (Okeke, 2015; Nzeakor, 2019; Uzo, 2021). Also, besides street hawking, Nigerian children do all kinds of work: they shine shoes, wash and guard cars, carry luggage, among others, whether genuinely or not, just because they have to or want to make money. Meanwhile, it is important to note that these children face a lot of risks during and after these works. For example, these children return late at night which poses health risks and exposes them to criminal indulgence (Udoh \& Joseph, 2012; Jacks et al., 2019). In addition, as identified by Udoh \& Joseph, street hawking impacts society negatively because it eventually lead to the under development of a nation (Udoh \& Joseph 2012).

- Street Begging: Like street hawking, begging has been viewed to be common in Nigeria and associated with juvenile delinquency (Tambawal, 2011; Bukoye \& Procedia, 2015). The causes of street begging have been observed to be poverty whether real or imagined (Tambawal, 2011; Bukoye \& Procedia, 2015; Owusu et al., 2018). Owusu - Sekyere et al argue that street begging helps to solve the challenges of living and poverty. On his part, Nzeakor identifies causes of street begging to be poverty, poor school performances and socioeconomic status (Nzeakor, 2019). Begging has been described as a behavior that is anti-social which involves asking for things that the beggar lacks or favour (Broun et., 2010)

One of the observations of Tambawal (2011) is that Islamic scholars who migrate from their villages to urban towns or cities in dry season, do so with some children (almajirai) who are intended to school in the towns or cities. However, the children are expected to cater for themselves in the area of feeding, clothing, as well as pocket money. He emphasized that dubious individuals have used such children to perpetuate crime and religious crisis.

From the foregoing analysis, it is deducible that child labour implies children who work for long hours either for their parents or for another person, for little or no wage at all, often under deplorable and oppressive conditions and which are harmful to their health. The UNICEF (1997) report on the state of world children describes this type of work as destructive and exploitative. For instance, a child who delivers newspapers before school might actually benefit from learning how to work, gaining responsibility and a bit of money; but if a child is not paid, he/ she is being exploited. Precisely therefore, the term 'child labour' goes beyond child labour formal work setting that poses a great to health and safety of a child to include street hawking that exposes a child to the hazard of the road and paedophiles (Okafor et al., 2004; Jones et al., 2016; McDowell et al., 2018). According to Amukam (1986), child labour simply implies that the child gets paid or does not get paid for work, just because he/she wants to make a living. In summary therefore, child labour connotes exploitation of children, prematurely taking adult roles, working long hours for low wages, damaging their physical and psycho-social health and denial of the opportunities for their education and recreation. 


\section{Juvenile Delinquency in Nigeria}

The United Nations convention on the right of the children 1989 (CRC or UNCRC) and the African Charter on the Rights and welfare of the child, 1990 ACRWC or children's Charter), defines a child as a human being under the age of 18 years. The children and young persons law (CYPL) defines a 'child' to mean a person who has attained the age of 17 (18 years in Kano state, Nigeria). This forms the basis of this study's discussion of juvenile delinquency. It therefore follows that a juvenile offender may be defined as any person under the age of 17 years who commits an offence or an act of omission that renders him liable to punishment under the law.

The concept juvenile delinquency has been defined in many related ways. Bartollas (1990) defines it as an act committed by a minor that violates the penal code of the government with authority over the area in which the act occurred. Alemika \& Chukwuma (2008) also defines juvenile delinquency as any act that violates criminal law, committed by anyone defined by law as a juvenile, which if committed by an adult is treated as crime or criminal conduct. Broadly speaking therefore, delinquent acts are attitudes or behaviors which constitute crime for adults but are defined as juvenile delinquency when manifested by children and young persons (Nwanne, 2003; Hassan et al., 2020; Raab et al., 2001; Vaitkevičius et al., 2015). Such acts which are referred to as status offences include diverse behaviours like truancy, running away form home and beyond parental control. Others are loitering, drinking alcohol in public, associating with disputable persons, that is criminals, prostitutes and others. Most vulnerable in this regard are children living in the streets and are often apprehended on the ground of status offences. It therefore implies, that juveniles are subjected to wider legal restrictions and differential treatment within the criminal justice system.

Writers such as Udoh \& Joseph (2010), Adiotomre (1980), Avwata (1983), and Oniyama (2000) identify stealing, dishonesty, disobedience, insult, truancy, sex offences, drug abuse, wickedness, examination malpractice, gangsterism, fighting and suicide as common delinquent behaviours in Nigerian secondary schools. In recent times and in several parts of the world, many people are interested in studying crime because it is a serious social problem that demands urgent solution. In Nigeria as rightly identified by Nkpa, crime poses an immediate threat to many people as everyone is aware of the harm done by crime (Nkpa, 1981).

A very disturbing aspect of delinquency has been witnessed in the past few years in the activities of the ethnic militia such as the Odua Peoples Congress (OPC), the Egbesu Boys, the Bakassi Boys, and the Indigenous people of Biafra (IPOB). Street hawkers/beggers face the danger of being recruited into organized crimes such as hawking drugs, terrorism, armed robbery, thuggery or gangism and banditary and are also used to perpetuate ethnic conflicts. Many young children hawking and selling or begging on the streets of Nigeria also combine organized stealing popularly tagged '419' (Advance fee fraud ). According to Goldmark (1904) school children news street trade in England, is "specifically designated a hot-bed of vice and crime" (Gold mark, 1904). The same can be said of children street trade/ begging in Nigeria today.

\section{Implications of the effects of child labour on delinquency rate for human and capital development}

A key aspect of moral turpitude is corruption. Child labour by exposing children to the streets and all kinds of morally bankrupt people most often corrupts children and initiates them into delinquent behavior. The increasing criminality of the young population of the Nigerian society has serious implications for both the children and the nation at large. One may argue, that in a developing nations such as Nigeria with traditional norms and values, a child labour such as street hawking and domestic service prepares a child for greater responsibilities and challenges ahead but it has a lot of negative effects for the future of the Nigerian children. Not only is the child's childhood ruined by being deprived of affection and other things such as adequate and functional schooling, play and so on, but his / her future is also ruined.

Such is as a result of what studies have shown: that delinquency and anti-social patterns of behavior developed as a result of child labour disrupts their academic, moral, social, and physical growth and development (Nte, 2005; Udoh \& Joseph, 2011; Okeke, 2015; Jacks et al., 2019; Hassan et al., 2020). According to Baland \& Robinson (2000), children who are involved in child labour, "suffer verbal abuse, low self esteem and a loss of imagination and future direction" (Baland \& Robinson, 2000). It is important to note that abused children are vulnerable to delinquent behavior. On their part, they are potential for delinquency is high among street hawkers and leads to their underdevelopment.

Further still, children or young persons who have been convicted or held in custody for crime may carry with them a label of criminality. The label may be that of a thief, cultist, drug addict, sex-maniac, robber, drunkard or alcoholic, rapist, killer, '419', and others. As a result, other people will begin to deal with the person in terms of the label that has now been affixed and the label itself will have more significance than any other status the person holds. 
Wherever the person goes, his/ her record follows him/ her thereby becoming a hindrance to a bright and promising future for the one that is labeled.

This does not augur well for human development. As observed by Jike (2004), while adults represent the present, children represent the future. In his own words, "this futuristic role of the child and its implication for institutional continuity and discontinuity is the main reason why the child must be protected in the present, so that we can realize its full potential in the future" (Jike, 2004). In terms of capital development, delinquency breeds fear and insecurity in the society. Nigerians do not feel safe anywhere: at home, work, airports, on the highways and even within the hallowed precincts of places of worship and this does not make room for national development (Jike 2003; Tambawal, 2011). Udoh and Joseph corroborates this point as they emphasis that street trading because of it is negative effect such as the influence of criminal peer groups on children and young persons, impact negatively on society and in the long term results to underdevelopment in the nation (Udoh \& Joseph, 2012).

\section{Theoretical Framework}

Various theoretical formulations have been advanced to explain the growing incidence of child labour and juvenile delinquency, especially in the developing countries. For this study, Durkheim's theory of anomic and Robert Merton's theory of social structure and anomie forms the theoretical basis. According to Durkheim (1955), where the limits between what is possible and impossible, just or unjust are unknown, a state of normlessness, or anomie and frustration occurs. This condition is exacerbated by rapidly changing values, from those informed by morality and patriotism to those induced by the struggle over limited access to scarce material and political offices and resources. Also involved in these human ambitions, are insatiable and unattainable goals. One's satisfaction of a goal stimulates another and the more one has the more one wants to have.

Maladministration, characteristic of government in Nigeria even in post-military era has largely been a function of economic crimes, which in turn precipitated institutional collapse. Under the condition of anomie, depraved people or socially and economically dislocated families engage the children in all kinds of obnoxious labour to satisfy their ever changing and increasing aspirations and goals. This phenomenon of child labour which involves physical and non-physical acts ravage not only the individual involved but also the whole society. In this instance, Merton (1957) throws more light on Durkheim's anomie and it becomes apparent that society exerts pressure on certain individuals to be non-conformist rather than conformist to expectations.

Merton postulates that anomie results from the strains on the social structure that pressurize individuals into illegal aspirations. He does not leave anyone in doubt that deviance results from the culture and the structure of the society. This is because members of the society are placed in different positions in the social structure. For example, if members of the society differ in terms of class or positions or have different opportunities of realizing the shared values of the society, deviance will arise and certain persons may use illegal means in attaining the goals or values of the society. Using the United States of America as a case study, Merton discovers that the major value of American culture has to do with the goal of success which is largely measured by wealth or material possessions. He also observes that, in America, the accepted means of achieving success are through hard work, ambition, talent, determination and education.

However, while little or less emphasis is placed on acceptable means of achieving success, great emphasis is laid on the success itself. Therefore, there is the tendency to reject the 'rule of the game' and to strive for success through any other available means. It, therefore, follows that when rules fail to operate, a situation of anomic or normlessness will arise. Merton, therefore, implies in his theory that culture determines norms about goals and means, and it also determines expectations and aspiration levels. Structure restricts goals achievements and access to means. Frustration becomes the result of hindrance from achieving cultural goals, and anomie is the erosion of norms due to inability to follow them. It therefore, means that delinquent acts are caused by frustration and anomie.

Merton further highlighted five ways through which individuals usually adapt to the frustration or strain which is generated by the culture and structure of their societies as far as achievement is concerned. The five responses are conformity, innovation, ritualism, retreatism and rebellion. Society has effectively socialized the individual that conforms to seek cultural goals according to normative means. So he accepts the culturally approved goals and norms. Other individuals may accept the goal of success while rejecting conventional means to achieving the goal. $\mathrm{He}$ argues that innovation results from the 'strain' experienced when an individual tries to adopt the legal or acceptable way of achieving success all to no avail. This happens when the value placed on wealth overpowers the norms that regulate how wealth is to be acquired. Obviously, the poor, the down-trodden, the unemployed, and others, experience the strain to the extent that their aspirations for success are frustrated by lack of education and job 
opportunities. Some resort to making their own rules in the form of theft/robbery, selling illegal drugs, street violence, hustling and racketeering.

The ritualists resolve the strain of having realized the cultural of wealth by simply abandoning the goals and at the same time placing greater emphasis on conforming to cultural norms in order to gain respectability. The next response or adaptation to the inability to achieve wealth according to Merton is retreatism. This refers to the rejection of both the goals and the norms of the society. Retreatists are society's dropouts. This category includes alcoholics and drug addicts as well as many of the street people commonly found in American cities. The last response to the failure to achieve wealth or success is rebellion. Like the retreatist, they reject both the cultural definition of success and the normative means of achieving it. Rebels, however, go further by advocating some radical alternatives to the existing social order, including new cultural values and norms. Some seek to do this through political revolutions, while others promote unconventional religious groups. In any case, the rebel withdraws from established society and embraces some counter culture (this is, subculture).

From the foregoing theoretical analysis, it is clear that both Emile Durkheim's anomic theory and Merton's theory of social structure and anomic can be used to explain child labour and juvenile delinquency in Nigeria in particular. This is mainly because the combined effects of maladministration and anomic are inflation, food shortages, unbearable transportation costs, unemployment and other socio-economic malfunctioning which have penetrated deep into the entire society and the poorer low class citizens engage in their own forms of economic crime and other anti-social activities as the available means of success.

In the process of such manifestations of maladministration and amonie, the family which is the building bedrock of society becomes weakened in both structure and function as both parents engage in economic activities where they have the opportunity for survival at the expenses of the proper socialization of their children. They may innovate means to survive by sending them to work to supplement households' income and children who have no means of survival might resort to hawking, petty trade, sex work, and others in order to make both ends meet. Also, when children find themselves in crisis situation at home, school, and in society generally, if the pressure upon them become unbearable they may take to delinquent acts or behaviors as alternative courses of action. For instance, a female university undergraduate who suddenly finds that her parents can no longer pay her school fees may be driven into prostitution. A male counterpart may be driven into sale of hard drugs and drug addiction or be frustrated into cultism and violence or rebellious behavior.

Idowu (1992), expresses her mind on parents negligence of their children when she opined that peoples' crave for wealth and position have left children on their own to take care of life as best as they can. In Okonye's view (Okonye, 1960), juvenile delinquency arises from poor environmental circumstances and poor home upbringing to which the child is exposed before going into the society. However, Ozigi (1991) attributes the cause of juvenile delinquency to the school administrations. He points out that some school heads and teachers alike do not treat the young boys and girls of the junior secondary school well. Student complaints are not looked into, hence the young ones take the law into their hands and fight for themselves. Such situations infuriate the young ones to riotus and rebellious actions that cause much harm. According to Nyong (2002), students themselves are good weapons of indiscipline in homes, at schools, and in the society. They would rather join anti-social groups instead of being members of well-behaved groups.

\section{Conclusion}

On the basis of the above considerations, the study concludes that child labour directly and indirectly leads to juvenile delinquency and encourages it. Both activities are still very prevalent in Nigeria and are hindrances to human development and national growth and development. They create frustration and a state of hopelessness generally. Child labour is cruel, obviously short-sighted, unfair to the child, and of course an economic waste for Nigeria.

\section{Recommendations}

There is an urgent need to revive the traditional values and standards of the Nigerian society as well as balance the structure of society in such a way that all classes of people are accommodated and not marginalized. This will go a long way in minimizing illegal means or behavior of achieving legitimate goals and other means of achieving illegitimate goals. Also the family institution needs to be strategically helped to take the leading role in the socialization of its members. Other recommendations that will minimize to a tolerable degree the existence of child labour and juvenile delinquency are proffered as follows: 
- Economic reforms agenda of the present government, must be given a human face because of the hardships it has brought to various institutions especially, the family. A reform might be beautiful but is useless if it is not focused on people.

- All the provisions of the child rights Act (2003), should be implemented by all the state governments especially, as they affect free and compulsory education at all levels. This will not only helps to ameliorate the burden of high school fees on parents but will also keep the children off the streets.

- Trained social workers (welfare officers) should be attached to families

- A wholesome school programme should be put in place and virile parents - teachers Association should be established to enhance school - community relations.

- Effect and time bound measures are urgently required to stop recruitment of new child laborers to prevent the engagement of children in the worst forms of child labour, to provide the necessary and direct assistance for the removal of children from the worst forms of child labour and for their rehabilitation and social reintegration. Decent rehabilitation centers and proper rehabilitation programmes should be developed also for delinquent children.

- Large family size has often been identified as the cause of poverty in Nigeria. Therefore both rural and urban communities should be well informed through enlightenment campaigns by government and nongovernmental agencies on its disadvantages. People should be encouraged or even assisted towards limited family size that will be defined by government.

\section{References}

Adiotomre, J. (1998). Introduction to Education Administration. Warri, Nigeria: COEWA publishers

African charter on the Rights and welfare of the child (ACRWC) (1990). Adopted by the organisation of African Unity (OAU).

African Union (2019). African Union Action Plan towards the eradication of child labour and modern slavery on the continent. Business and Human Rights Resource centre. www.business-humanrights.org

Alemika, E.E. O \& Chukwuma, I.C (2008). Juvenile Justice Administration in Nigeria: Philosophy and practice. Ikeja, Lagos, Nigeria: centre for law Enforcement Education.

Ammani, A. A. (2009). Street begging: exposing the effect of blatant paying of lip service. http://www.ganji.comarticles8oo/news8196.htm

Avwata, B. (1983) A modern Sociology of Education: A systematic Analysis. Warri, Nigeria: COEWA publishers

Baland, J. \& Robinson, J. A. (2000). Is child labour inefficient? Journal of political Economy 88 (3), 412-427.

Bartollas, C.B (1990). Juvenile Delinquency. New York: Macmillan publishing company.

Bingen, J., Serrano, A., \& Howard, J. (2003). Linking farmers to markets: different approaches to human capital development. Food policy, 28(4), 405-419. https://doi.org/10.1016/j.foodpol.2003.08.007

Broun I. B, Ube, M. \& Bisong, M. D. (2010). Counseling youth against drugs abuse: implication for human development conference proceeding $34^{\text {th }}$ Annual SCASSON conference p20-28.

Bukoye, R. O. \& Precedia (2015). Case study: prevalence and consequences of streets begging among adults and children in Nigeria, Suleja metropolis. Social and Behavioural Sciences, 17 (2015), 323 -333

Child Abuse, Prevention and Treatment Act (1994). The Human services Amendments (P.L. 103 - 252, 5/19/1994).

Child Rights Act (2003). Laws of Nigeria. lawsofnigeria.plcing.org >laws.

Čiutienè, R., \& Railaite, R. (2015). A development of human capital in the context of an aging population. ProcediaSocial and Behavioral Sciences, 213, 753-757. https://doi.org/10.1016/j.sbspro.2015.11.463

Currie, J., \& Almond, D. (2011). Human capital development before age five. In Handbook of labor economics (Vol. 4, pp. 1315-1486). Elsevier. https://doi.org/10.1016/S0169-7218(11)02413-0

Darcy, S., Maxwell, H., Edwards, M., Onyx, J., \& Sherker, S. (2014). More than a sport and volunteer organisation: Investigating social capital development in a sporting organisation. Sport Management Review, 17(4), 395-406. https://doi.org/10.1016/j.smr.2014.01.003

Durkheim, E. (1955). Anomie suicide. In Stein H.S \& Cloward, R. A, Social Perspective on Behaviour Ilonois: the Free Press

Ekpeyong, S.N. \& Sibiri, A.E. (2011). Street trading and child labour in Yenegoa. International Journal of scientific Research in Education, 4 (1), 36 - 45.

Elembah, D. (2012). Nigeria, the turbulent North and the Almajrai threat cited in Bukoye, R. D/procedia (2015), case study: prevalence and consequences of streets begging among adults and children in Nigeria Suleja metropolis. Social and Behavioural Sciences, 17 (2015), 323 - 333. 
Esiri, M. O. (2020). A sociological Analysis of women poverty related crimes with special reference to violent crimes, drug trafficking and human trafficking in Nigeria. International Journal of psychosocial rehabilitation, 24 (05), $1475-7192$.

Esobonu, O. U. (2012). An influence of socio-economic status of parents on children development. Journal of sociology, 4 (2) 64-80

Fahimi, A., Saint Akadiri, S., Seraj, M., \& Akadiri, A. C. (2018). Testing the role of tourism and human capital development in economic growth. A panel causality study of micro states. Tourism management perspectives, 28 , 62-70. https://doi.org/10.1016/j.tmp.2018.08.004

Galli, E. B., \& Müller-Stewens, G. (2012). How to build social capital with leadership development: Lessons from an explorative case study of a multibusiness firm. The Leadership Quarterly,23(1), 176-201. https://doi.org/10.1016/j.leaqua.2011.11.014

Goldmark, J. c. (1904). Street labour and juvenile delinquency. Political science Quarterly, 19 (3), 417-438.

Handbook of crime and criminal Justice (2011) ed. Michael Tony. Oxford publishers www.oxforshandbooks.com

Hassan, I. M. , Akunesiobike, C. A. \& Uguoke, O, C. (2020). The nexus of street trading and juvenile delinquency: A study of Chanchaga Local Government Area of Niger State, Nigeria. International Journal of Research and Innovation in Social Science(IJRISS), IV(V), $2454-6186$.

Idowu, S.O. (1992). How close are you to your child? Sunday observer February 19 Benin - city, Nigeria

ILO (1996) international labour conference on child labour: Targeting the intolerable. General ILO publication

ILO (1998). International conference on child labour. Geneva: ILO publications

Jacks, S., Ekeng, E. B \& James, O. E. (2019). Characterization of delinquencies associated with street juvenile hawkers in Calabar, cross Rivers state, Nigeria. International Journal of innovative social sciences Research, 7 (2); 21-26.

Jike, V.T. (2004). Child Labour and the Problem of Institutional Discontinuities in Nigeria. Journal of Trade and Issue in Crime and Criminal Justice.

Jones, L., Norton, L., Austin, Z., Browne, A. L., Donovan, D., Emmett, B. A., ... \& Willis, G. F. (2016). Stocks and flows of natural and human-derived capital in ecosystem services. Land use policy, 52, 151-162. https://doi.org/10.1016/j.landusepol.2015.12.014

Joshi, S. (2020). Juvenile delinquency. http://www.legalservicesindia.com. Accessed February 23, 2021

McDowell, W. C., Peake, W. O., Coder, L., \& Harris, M. L. (2018). Building small firm performance through intellectual capital development: Exploring innovation as the "black box". Journal of business research, 88, 321327. https://doi.org/10.1016/j.jbusres.2018.01.025

Merton, R. K. (1957). Social Theory and social Structure. Glencoe III: Free press

Monitoring programme on child labour (IPEC - Simpoc) (2006). www.ilo.org

Nelson, N. and Clark, K. (1986). The educator's guide to preventing child sexual abuse. Santa: Network publications.

Nte, N.D. (2005). The Political Economy of Child Labour in a depressed economy: the case of Port Harcourt city, Nigeria. In Ifeanacho, M. (Ed.) The Socio-Antrop Perspective of African Development Crisis. A publication of the department of sociology, Faculty of sciences, University of Port Harcourt, Nigeria.

Nwanne, O. C. (2003). Educational measurement for Teachers London: Nelson

Nzeakor, O.F. (2019). Juvenile Justice system: Nature of child labour and juvenile delinquency in Nigeria. www.researchgate.net Doi: 10.13140/RG.2.2.34216.62723 (project). Accessed March, 2,2021.

Okafor E. \& Bode - Okumade, A. (2004). Institutional collapse and child labour: The pervasive problem of street hawking in Nigeria. In V.T. Jike (ed). The Scourge of child Labour in Nigeria: A Book of Readings. Lagos: NISS publication.

Okeke, N. (2015). Poverty is driving a rise in the number of Nigeria child hawkers. The conservation. (theconservation.com) Accessed Feb 2, 2021

Okeshola M. B. (1996). Child labour. In The Rights of the child in Nigeria, Aya, I. A \& Okegbue, I. E (eds). Lagos

Oloko, B. A. (2003). Child labour and trafficking in Nigeria key Issues: Paradigms E: methodologies, and measures (ed.)

Oniyama, H. \& Avwata, B. (2000). Adolescent students and Drug Abuse in Nigeria. Paper presented at $1^{\text {st }}$ Annual conference of the Nigerian society of Educational psychologists (MSEP) Nnamdi Azikiwe University Awka 9-10 October.

Owusu - Sekyere, E., Jengre, E. \& Alhasan, E. (2018). Begging in the city: complexities, degree of organisation and embedded risks. Child development research, Vol. 2018, Article Id 9863410, 9 pages https://doi.org/10 1155/20189863410, Accessed February 23, 2021 
Raab, R. T., Ellis, W. W., \& Abdon, B. R. (2001). Multisectoral partnerships in e-learning: A potential force for improved human capital development in the Asia Pacific. The Internet and higher education, 4(3-4), 217-229. https://doi.org/10.1016/S1096-7516(01)00067-7

Shinadu, J. (1986). Parents loss and child labour in Northern Nigeria.

Tambawal, M. U. (2011). Effects of street begging on National Development: counseling implications. Oer.udusok.edu.ng >handle. Accessed March 21, 2021

Udoh N. A. \& Joseph, E. U. (2012). Behavioural problems of juvenile street hawkers in Uyo Metropolis, Nigeria. World Journal of Education, 2 (1), 137-144

Ukpa, No (1981). Criminology and Penology. In Otite, O. p.269-270

UNICEF (1990). The state of the World's Children pubdoc@unicef.org

UNICEF (1997): State of World's Child Report. New York

UNICEF (2001) children and women rights in Nigeria: A wake-up call (situation assessment and analysis), Abuja: National planning commission

Uzo, U, (2021). Analysis of Business Problems. Lagos Business Problem: Lagos Business School Site, Pan Atlantic University. Accessed March, 2,2021.

Vaitkevičius, S., Čiutienė, R., Meilienè, E., \& Savanevičienè, A. (2015). Typology of human capital development in EU countries. Procedia economics and finance, 23, 1641-1648. https://doi.org/10.1016/S2212-5671(15)00520-1

Vinolia, N. S. \& Fuhura, S. W. (1986). Street hawking as an aspect of child abuse and negbict. In P. O. E. Ebigho et al, (eds.) OPcit

World Bank (1990). World Development Report: Poverty. New York: Oxford University Press. 